\title{
EFFECTIVENESS OF LEARNING THE DIGITALIZED HISTOLOGY IMAGES IN PRACTICAL TEACHING FOR I YEAR MBBS STUDENTS
}

\author{
Vidya CS ${ }^{* 1}$, Vidya G Doddawad ${ }^{2}$.
}

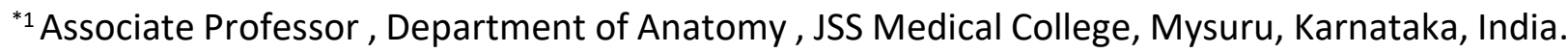

${ }^{2}$ Reader, Department of Oral Pathology and Microbiology, JSS Dental College and Hospital, Jagadguru Sri Shivarathreeshwara University, Mysuru, Karnataka, India.

\section{ABSTRACT}

Introduction: Histology course for I MBBS students includes more than sixty two histological sections which need to be taught in limited time allotted for histology laboratory. Learning to recognize and appreciate the histological features remain a difficult and time-consuming task for many.To improve the identification skills of the students, hence we introduced a module containing digital histology slides.

Aim: To develop and introduce a self-instructional digitalized histology images through computer-aided approach to guide the students learning in the first-year histology course of MBBS students and compare them with the traditional method of learning

Materials and Methods: High quality histology glass slides were converted into digital histology images using research microscope with software under $100 \mathrm{X}$ and $400 \mathrm{X}$ magnifications. The final digitalized images were implemented into e - module and digital histology slides were distributed among students $(\mathrm{N}=140)$. To evaluate this new technique group consisted of 140 first-year students who were taught the histology slides via digitalized images. To assess the knowledge and the learning outcome from digitalized learning method a question based survey was conducted.

Results: Overall, students responses to the questionnaire were positive with an overall mean level of agreement for all eight responses of 4.5 out of 5 (90 percent). The usage of microscope, resolution and quality of the images, magnification and clarity of the image is superior in digital histology images than the traditional/ conventional microscope

Conclusion: Computer aided learning and digital images provide the opportunity for students to view them at their convenient time, better learning and interpret the same during practical sessions and examination. Hence, the traditional/ conventional microscope should replace the virtual microscope in all medical schools at the earliest.

KEY WORDS: Digital histology/pathology slides, e-learning, Medical education, Research microscope, traditional/conventional microscope.

Address for correspondence: Dr Vidya CS, Associate Professor, Department of Anatomy, JSS Medical College, Jagadguru Sri Shivarathreeshwara University, Mysuru-15, Karnataka, India.

E-Mail: vidyasatish78@rediffmail.com

\begin{tabular}{|c|c|c|}
\hline \multicolumn{3}{|c|}{ Online Access and Article Informtaion } \\
\hline \multirow{2}{*}{$\begin{array}{c}\text { Quick Response code } \\
\text { DOI: } 10.16965 / \text { ijims.2017.108 }\end{array}$} & \multicolumn{2}{|c|}{$\begin{array}{l}\text { International Journal of Integrative Medical Sciences } \\
\qquad \text { www.imedsciences.com }\end{array}$} \\
\hline & $\begin{array}{l}\text { Received: 02-08-2017 } \\
\text { Reviewed: 02-08-2017 }\end{array}$ & $\begin{array}{l}\text { Accepted: } 20-08-2017 \\
\text { Published: 05-09-2017 }\end{array}$ \\
\hline Source of Funding: Self & \multicolumn{2}{|c|}{ Conflicts of interest: None } \\
\hline
\end{tabular}

\section{INTRODUCTION}

Digital slides are proving to be boon for education of undergraduate and postgraduate students' in the microscopic world. Traditional histology teaching is teacher centered with a heavy emphasis on acquiring factual knowledge. As reported by previous studies computer aided learning allows digital images to be viewed as if using a bright field microscope. The procurement and maintenance of microscopes 
and stained tissue mounted on glass slides are costly [1].

The quality of health care delivered to patients begins at the cellular level and is closely linked with making correct histopathology diagnosis.

Anatomy/histology has an established value in medical education and is supported by students, clinicians, anatomists and the general public. Microscopy of Histology/Pathology specimen is mandatory of practical classes used to teach and explain the normal structures and disease process. The traditional/ conventional light microscope used as a teaching device for the same. Generally, it is disliked by the students as they complain about the quality and consistency of its use. It declines the interest in anatomy as well as histology/pathology, a result of change in time and a resource allocated to teaching or is it a result of the changes in teaching methodology [2].

With this context, there is a strong demand and necessity to train medical graduates in par with global standard. Hence, a major shift in the design of newer learning approach like digital microscopy technology should be introduced in the course.

\section{MATERIALS AND METHODS}

Questionnaire based survey was undertaken in the Department of Anatomy, JSS Medical College, Mysuru. The study group students $(\mathrm{N}=140)$ were given digital histology images. High quality histology glass slides were photographed at the microscopic level using research microscope of 100X and 400X magnification. The digital images were subsequently enhanced

Frequency distribution $(n=140$
Fig. 1: Digital library with computer work station to learn the digital histology slides.

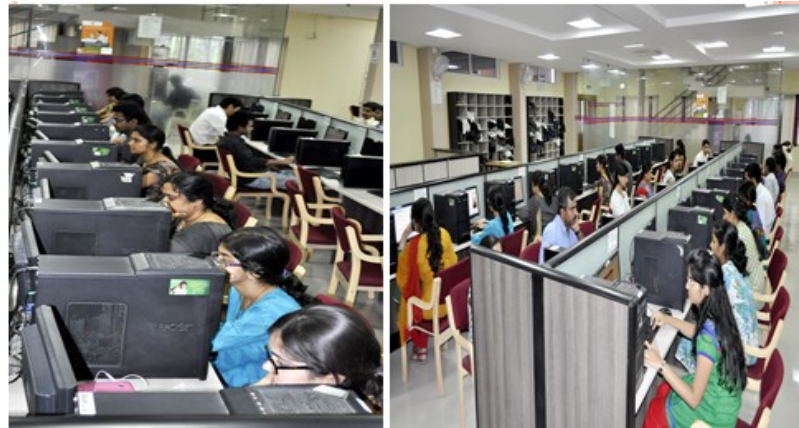

Fig 2: Digitalized histology image with schematic representation of thick skin.

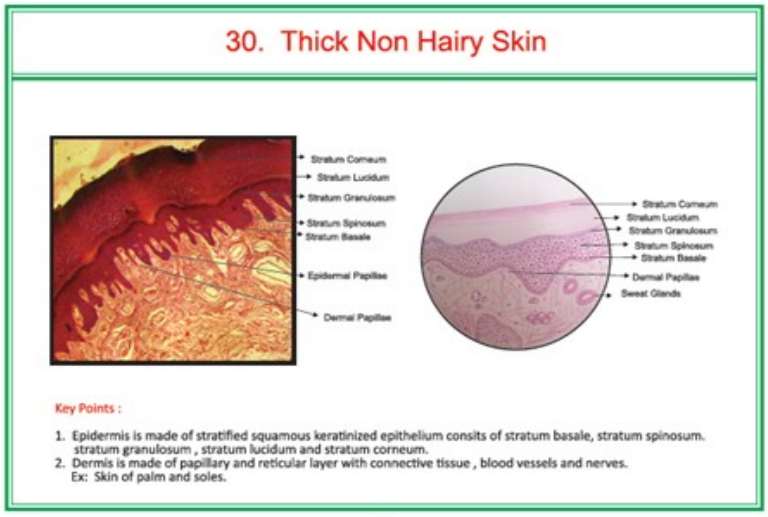

with computer software and cropped to actual size (Fig 2) A4-sized photomicrographs of practical slides and pre-practical briefings were done. Implementation of digitalized learning was assessed by using a question based survey which was produced after a period of six months. Responses were based on a scale of 1-5 (strongly disagree, disagree, agree, strongly agree and uncertain). The survey addressed on the instructional environment, student learning, efficiency of laboratory instruction, and product feedback. The statistical analysis was done to analyze the collected data.

\section{RESULTS}

Table 1: Shows student feedback response for Histology CD.

\begin{tabular}{|c|c|c|c|c|c|}
\hline Questionnaire & $\begin{array}{c}\text { Strongly } \\
\text { Agree } \\
1\end{array}$ & $\begin{array}{c}\text { Agree } \\
2\end{array}$ & Disagree & $\begin{array}{l}\text { Strongly } \\
\text { disegree } \\
4\end{array}$ & $\begin{array}{c}\text { Uncertsin } \\
5\end{array}$ \\
\hline The content of the material in the digital histology was interesting & 95 & 69 & 8 & 5 & 2 \\
\hline The informstion presented in the digital content wes wseful & 42 & 76 & 9 & 10 & 3 \\
\hline Digital histology slides wos an effective learning method & 65 & 58 & 3 & 5 & 5 \\
\hline $\begin{array}{l}\text { The slise imsges and diagrams mase the information cesier to } \\
\text { unserstand }\end{array}$ & 29 & 68 & $s$ & s & 4 \\
\hline $\begin{array}{l}\text { I would prefer using digital CD rather than viewing slises with a } \\
\text { trasitionsl microscope }\end{array}$ & 69 & 56 & 5 & 6 & 4 \\
\hline $\begin{array}{l}\text { The digital content wes simple to wse and implicate during practical } \\
\text { sessions }\end{array}$ & 98 & 70 & s & 4 & 3 \\
\hline $\begin{array}{l}\text { I enjoy dosses that wse a combination of tesching methods induding } \\
\text { troditional lectures, labs and e lesrning tutorials }\end{array}$ & 74 & 42 & 12 & 8 & 4 \\
\hline $\begin{array}{l}\text { The isentification of histology slibes wes essier in practical sessions } \\
\text { sfter the use of } \mathrm{CD}\end{array}$ & 48 & 72 & 10 & 7 & 3 \\
\hline $\begin{array}{l}\text { The isentification of histology slises wos essier in interngl } \\
\text { susessment after the use of CD }\end{array}$ & 68 & 99 & 7 & 4 & 2 \\
\hline
\end{tabular}


Graph 1: Perception of students for digital histology slides.

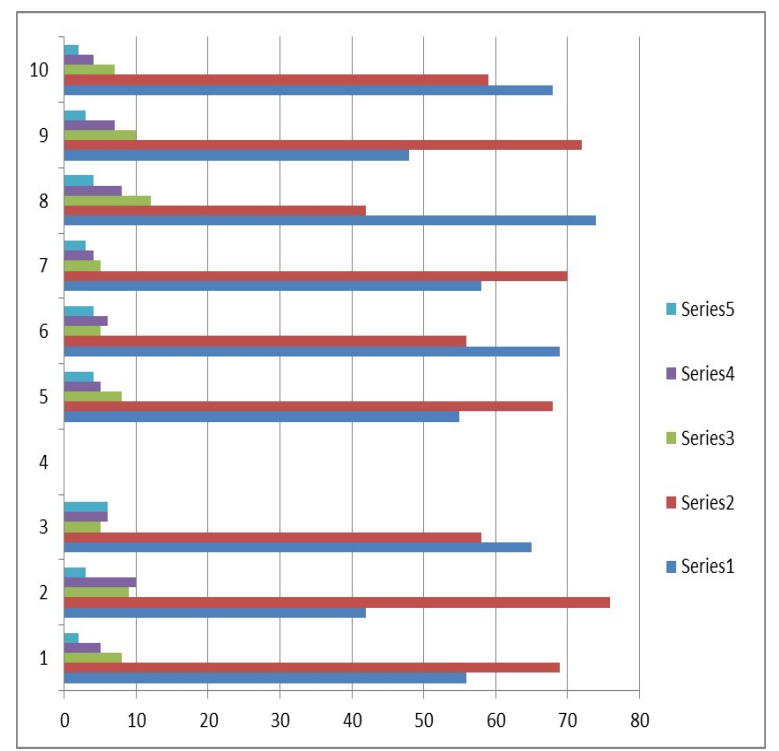

\section{DISCUSSION}

Over the years, the medical curriculum has undergone multiple improvements and changes. The basic sciences module seemed to fall behind at its level but the new method in teaching has helped it to catch up. The new medical curriculum required in teaching to move into a more digital imaging form in this digital era. Improvements have been made in order to move from a passive highly detailed teaching of these studies to a more functional and clinically relevant method [3].

Sally Krasne et.al were adapted a new approach for enhancing pattern recognition of basic pathologic processes in skin histopathology images that utilizes perceptual learning techniques, which allowed learners to see relevant structure in novel cases along with adaptive learning.They developed a perceptual and adaptive learning module (PALM) by utilizing 261 unique images of both pathology and normal histology at low and high magnification. They observed that accuracy, response, time to diagnose and scores significantly improved from the pre- to post-test with scores showing much greater improvement than accuracy alone [4].

Jyotsna $V$ et.al were studied and reported that a new practical teaching methodology were introduced and more emphasized on clinicopathological correlation for 120 number II year M.B.B.S. students and 8 postgraduate students in the Department of Pathology, KIMSU. They
Graph 2: Mean level of agreement for questionnaire on five point liker scale.

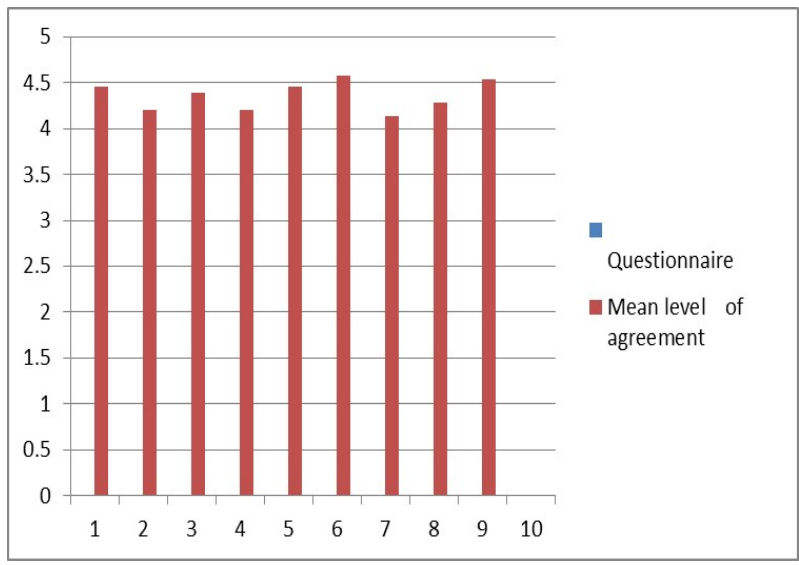

evaluated student and tutor perception of the new practical teaching approach by analyzing responses to Likert-scale based standardized questionnaires. Their survey stated that there were both encouraging aspects- namely, use of audio-visual aids and A4-sized photomicrographs of practical slides, prepractical briefings, formation of smaller groups for practicals- were appreciated; and others-namely, the materials/equipment used in teaching and time management during practicals - that need more efforts from both teachers and students to achieve the objective of learning pathology [5].

In a previous study by Subitha K and others at Govt. Medical College Kerala, they converted 20 glass slides into Digital images and were made into a CD. The study material was distributed to total number of 30 students, among them 15 students were randomly selected by lot method and they were the study group and the rest 15 students were the control group.. Assessment was done for both groups as a post test in the form of a spotter exam which included 10 slides and 10 specimens. The study reported mean improvement by the newer method was found to be 18.6 with a standard deviation of 23.3 and this improvement was statistically significant as $t=2.87$ and $p$ value $<.01$.The mean score obtained by the students by conventional method was $53 \%$ whereas the mean score obtained by the students by the newer method was $67 \%$ [6].

\section{CONCLUSION}

In the present era of digitalization, it is indeed necessary for us to keep on upgrading and 
evolving in the teaching methodologies, so that the students get the benefit the most.

Since the students are at a stage of learning the fixed views of the focused slides and not involved with diagnosis, it will definitely benefit them if the digital image technology replaces the conventional microscopic teaching aid.The learning process and acceptability is more desirable in digital image technology than the conventional microscope and it should replace in all medical/dental school's curriculum at the earliest.

\section{REFERENCES}

[1]. Harold Rosenberg, D.D.S. Effectiveness of an Electronic Histology Tutorial for First-Year Dental Students and Improvement in Normalized Test Scores. Journal of Dental Education December 1, 2006;70(12):1339-1345.
[2]. BW Turney. Anatomy in a Modern Medical Curriculum. Ann R CollSurg Engl. 2007 Mar;89(2):104-107.

[3]. Hussein et al., Once Upon a Microscopic Slide: The Story of Histology J Cytol Histol 2015;6:6.

[4]. Sally Krasne, Joseph D. Hillman, Philip J. Kellman and Thomas A. Drake. Applying perceptual and adaptive learning techniques for teaching introductory histopathology. J Pathol Inform. 2013;4:34.

[5]. Jyotsna VW, Sujata S. Kumbhar and Deepti VM. An appraisal of innovation in practical teaching in anatomic pathology - A students' and teachers' perspective. Al Ameen J Med Sci 2014;7(1):58-64.

[6]. Subitha K. Lillykutty P, Sajith Kumar R, Kandamuthan $M$, Usha P. Effectiveness of a multimedia resource in histopathology practical teaching in medical undergraduates-a comparative study. Tropical journal of pathology and microbiology. 2016;2(3).

How to cite this article: Vidya CS, Vidya G Doddawad. EFFECTIVENESS OF LEARNING THE DIGITALIZED HISTOLOGY IMAGES IN PRACTICAL TEACHING FOR I YEAR MBBS STUDENTS. Int I Intg Med Sci 2017;4(5):493-496. DOI: 10.16965/ijims.2017.108 